\title{
Luteimonas cucumeris sp. nov., isolated a from cucumber leaf
}

\author{
Zhan-Bin Sun, ${ }^{1} \dagger$ Hui Zhang, ${ }^{2} \uparrow$ Xing-Fang Yuan, ${ }^{1}$ Yin-Xian Wang, ${ }^{1}$ \\ Dong-Mei Feng, ${ }^{1}$ Yi-Hua Wang ${ }^{1}$ and Yong-Jun Feng ${ }^{1}$ \\ ${ }^{1}$ School of Life Science, Beijing Institute of Technology, Beijing 100081, PR China \\ ${ }^{2}$ School of Life Science, Liaocheng University, Liaocheng, Shandong 252059, PR China
}

Correspondence

Yong-Jun Feng

fengyj@bit.edu.cn
The genus Luteimonas, in the family Xanthomonadaceae of the class Gammaproteobacteria, was first described by Finkmann et al. (2000) for aerobic, Gram-negative rods with Q-8 as the major ubiquinone and iso- $\mathrm{C}_{15: 0}$ as the predominant fatty acid. At the time of writing, the genus Luteimonas comprises six species with validly published names: Luteimonas mephitis (Finkmann et al., 2000), L. composti (Young et al., 2007), L. aestuarii (Roh et al., 2008), L. aquatica (Chou et al., 2008), L. marina (Baik et al., 2008) and L. terricola (Zhang et al., 2010).

A yellow rod, designated $\mathrm{Y}^{\mathrm{T}}$, was isolated from a cucumber leaf collected from Pinggu District, east Beijing, PR China, during the blossoming stage in May 2009. The leaf was surface sterilized (Rubini et al., 2005) and a sample of crushed tissue was incubated on nutrient agar (NA; Difco) at $30{ }^{\circ} \mathrm{C}$ for 3 days and a pure culture of strain $\mathrm{Y}^{\mathrm{T}}$ was obtained after subcultivation. Strain $\mathrm{Y}^{\mathrm{T}}$ was routinely cultivated on NA at $30{ }^{\circ} \mathrm{C}$ and preserved in $25 \%(\mathrm{w} / \mathrm{v})$ glycerol at $-80{ }^{\circ} \mathrm{C}$.

Cells were grown for $72 \mathrm{~h}$ and observed by light microscopy ( $\times 1000$; Olympus $)$ and transmission electron microscopy (JEM-1400; JEOL) to ascertain their morphology and size. Motility was examined by the hanging drop method (Mackie \& McCartney, 1989). The Gram-reaction was determined by using non-staining $\mathrm{KOH}$ method, as described by Powers (1995). Poly- $\beta$-hydroxybutyrate granule accumulation was tested by staining with Sudan black (Baomanbio) and observation by light microscopy. Tests for

†These authors contributed equally to this work.

The GenBank/EMBL/DDBJ accession number for the 16S rRNA gene sequence of strain $\mathrm{Y}^{\top}{ }^{\top}$ is $\mathrm{HQ874629}$. catalase, oxidase and hydrolysis of casein, gelatin, starch, DNA and Tweens 20 and 60 were performed according to the methods of Smibert \& Krieg (1994). Growth at 15, 20, $25,30,37,42$ and $45{ }^{\circ} \mathrm{C}$ was assessed in nutrient broth (NB; Difco). Growth at $\mathrm{pH} 4-10$ (at intervals of one $\mathrm{pH}$ unit) was determined by measuring the $\mathrm{OD}_{600}$ of cultures in $\mathrm{NB}$ adjusted with appropriate biological buffers (Chung et al., 1995) prior to sterilization. Growth with $0,0.5$ and 1.0 $10.0 \%(\mathrm{w} / \mathrm{v}) \mathrm{NaCl}$ (at intervals of $1.0 \%$ ) was tested in $\mathrm{NB}$ prepared according to the formula of the Difco medium. Anaerobic growth was determined after incubation in an anaerobic chamber (Thermo). Strain $\mathrm{Y}^{\mathrm{T}}$ was a Gramnegative, aerobic, and non-motile rod. Poly- $\beta$-hydroxybutyrate granules were not accumulated. The isolate was able to grow on NA, tryptic soy agar (TSA; BD, Difco) and R2A agar (BD Difco). After $72 \mathrm{~h}$ at $30{ }^{\circ} \mathrm{C}$ on NA, cells were $0.5-$ $0.6 \mu \mathrm{m}$ wide and $2.0-3.0 \mu \mathrm{m}$ long and colonies were approximately $1.5-2.0 \mathrm{~mm}$ in diameter, yellow and round with umbonate elevations and smooth edges. Strain $\mathrm{Y}^{\mathrm{T}}$ was able to grow at $20-40{ }^{\circ} \mathrm{C}$, at $\mathrm{pH} 6.0-8.0$ and with $0-3 \%$ $\mathrm{NaCl}$. The optimum growth conditions were $30{ }^{\circ} \mathrm{C}$, pH 7.0 and $0 \% \mathrm{NaCl}$. The isolate was catalase- and oxidase-positive and able to hydrolyse gelatin, starch and Tween 60 , but it could not hydrolyse casein, DNA or Tween 20.

Physiological and biochemical properties and enzyme activities were determined using the API $20 \mathrm{NE}$ and API ZYM systems (bioMérieux), respectively, and utilization of carbohydrates and organic acids was investigated using the GN2 MicroPlate system (Biolog), according to the manufacturers' instructions. The results are listed in Table 1 together with those of members of the genus Luteimonas obtained using the same conditions and methodology. 
Table 1. Differential phenotypic characteristics between strain $Y 4^{\top}$ and its closest phylogenetic neighbours in the genus $L u t e i m o n a s$

Strains: 1, Y4 ${ }^{\mathrm{T}}$; 2, L. aquatica LMG $24212^{\mathrm{T}}$ (Chou et al., 2008); 3, L. composti BCRC $17598^{\mathrm{T}}$ (Young et al., 2007); 4, L. mephitis DSM 12574 (Finkmann et al., 2000); 5, L. marina FR1330 ${ }^{\mathrm{T}}$ (Roh et al., 2008); 6, L. aestuarii $\mathrm{B}^{\mathrm{T}}$ (Roh et al., 2008). All strains grow under the same conditions and are positive for catalase, oxidase, gelatin hydrolysis, alkaline phosphatase, esterase lipase (C8), leucine arylamidase, acid phosphatase, valine arylamidase, naphthol-AS-BI-phosphohydrolase and utilization of L-alanyl glycine, glycyl L-glutamic acid and L-proline. All strains are negative for lipase (C14), $\beta$-glucuronidase, $\alpha$-fucosidase, glucose acidification, indole production, arginine dihydrolase, urease, assimilation of mannitol, gluconate, caprate, adipate and phenyl acetate and utilization of adonitol, myo-inositol, lactulose, raffinose, L-rhamnose, cis-aconitic acid, citric acid, D-glucuronic acid, 2-aminoethanol, 2,3-butanediol and DL- $\alpha$-glycerol phosphate. + , Positive; w, weakly positive; -, negative.

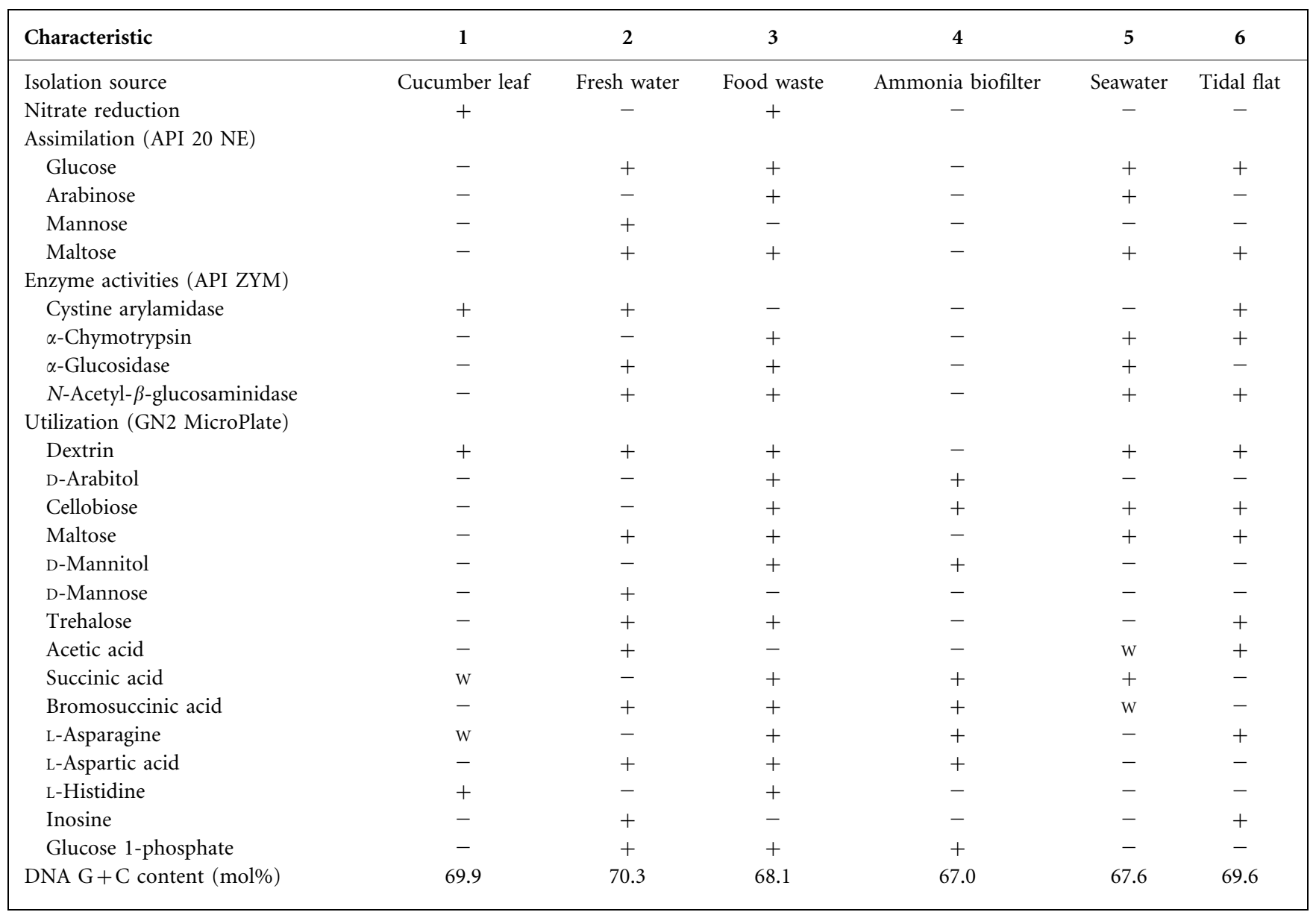

Genomic DNA for amplification was prepared as described by Rainey et al. (1996). The 16S rRNA gene was amplified using the universal bacterial primers $27 \mathrm{~F}$ and $1492 \mathrm{R}$ (Lane, 1991). The PCR products were purified and sequenced using procedures described elsewhere (Heery et al., 1990; Chun \& Goodfellow, 1995). The 16S rRNA gene sequence was compiled using Chromas version 1.43 (Conor McCarthy; Griffith University, Brisbane, Queensland, Australia). Sequences from related taxa were obtained from GenBank using BLAST (http://www.ncbi.nlm.nih.gov/) and aligned using CLUSTAL_X (Thompson et al., 1997). Phylogenetic analysis was performed using MEGA version 4.1 (Tamura et al., 2007). Evolutionary distances were calculated using the Kimura two-parameter model (Kimura, 1980) using neighbour joining (Saitou \& Nei, 1987) and maximum parsimony (Fitch, 1971). A phylogenetic tree was constructed using neighbour joining and bootstrap values were based on 1000 replications (Felsenstein, 1985). Similarity values were calculated using the EzTaxon server (http://www.eztaxon.org/; Chun et al., 2007). The 16S rRNA gene sequence obtained from strain $\mathrm{Y}^{\mathrm{T}}$ was a continuous stretch of $1454 \mathrm{bp}$. In the neighbour-joining tree (Fig. 1), strain $\mathrm{Y}^{\mathrm{T}}$ fell within the genus Luteimonas, which formed a distinct cluster that included the type strain of the type species of the genus. This cluster was supported by the maximum-parsimony analysis (data not shown). Strain $\mathrm{Y}^{\mathrm{T}}$ was most closely related to L. aquatica RIB1-20 ${ }^{\mathrm{T}}(96.7 \% 16 \mathrm{~S}$ rRNA gene sequence similarity).

Genomic DNA for the measurement of $\mathrm{G}+\mathrm{C}$ content and DNA-DNA relatedness was extracted according to the method described by Marmur (1961). The G + C content was determined by the thermal denaturation method (Sly et al., 1986), using a model Lambda 35 UV/Vis spectrometer 


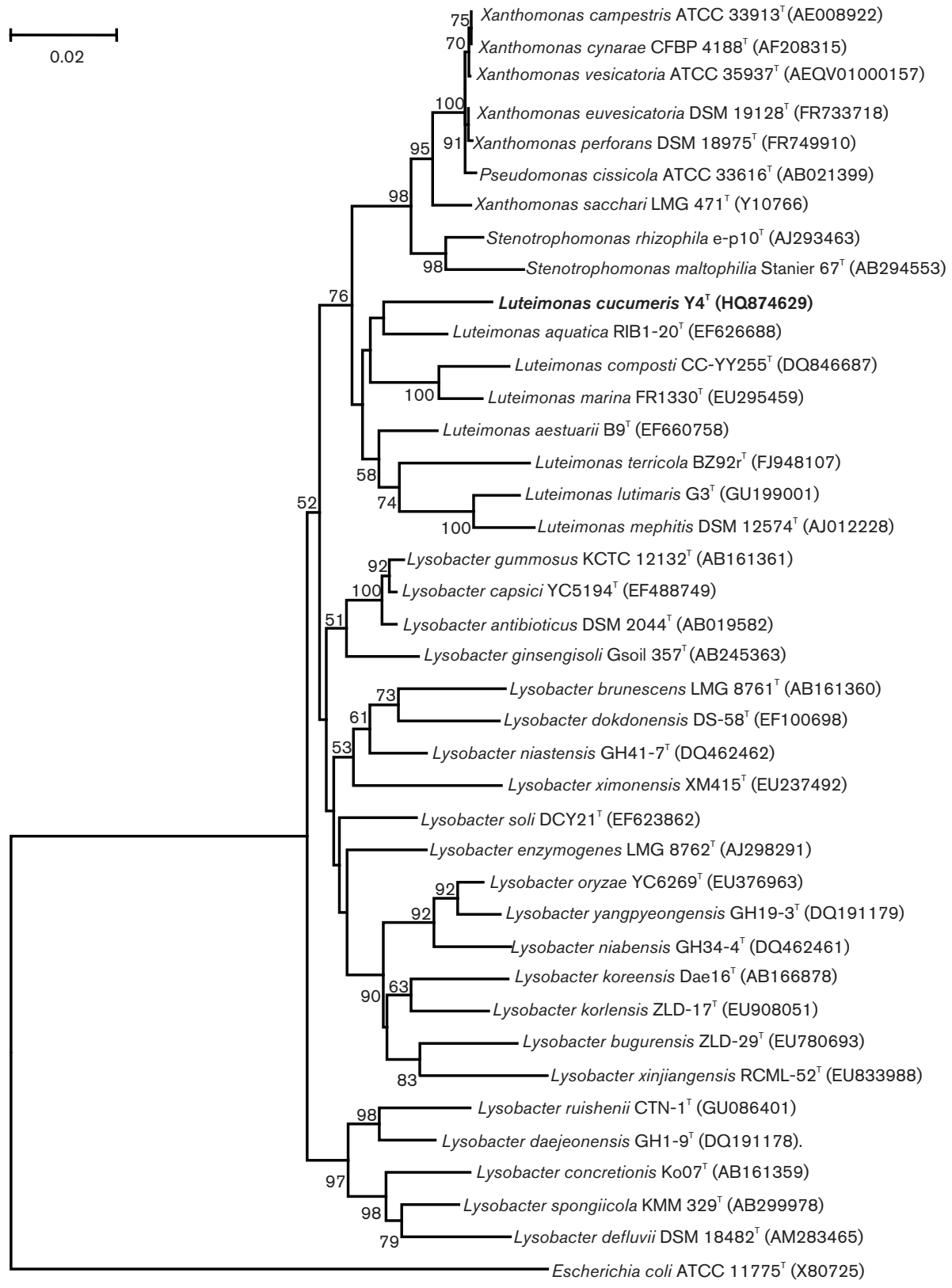

Fig. 1. Neighbour-joining phylogenetic tree based on $16 \mathrm{~S}$ rRNA gene sequences showing the relationships between strain $Y 4^{\top}$ and members of related species. Bootstrap values ( $>50 \%$ ) based on 1000 replications are shown at branch nodes. Bar, 0.02 substitutions per nucleotide position.

equipped with a thermometer controller (Perkin Elmer) and DNA from Escherichia coli $\mathrm{K}-12$ as a control. The DNA $\mathrm{G}+\mathrm{C}$ content of strain $\mathrm{Y} 4^{\mathrm{T}}$ was $69.9 \mathrm{~mol} \%$, which is in the range for the genus Luteimonas (64.7-72 mol\%). DNADNA relatedness was determined using a reassociationrate method, as suggested by Dong et al. (2000), and calculated according to De Ley et al. (1970). DNA-DNA relatedness between strain $\mathrm{Y}^{\mathrm{T}}{ }^{\mathrm{a}}$ and L. aquatica $\mathrm{RIB} 1-20^{\mathrm{T}}$ was $42.5 \pm 3.9 \%$ (mean \pm standard deviation of six replicates, $P=0.01$ ). According to the threshold of $70 \%$ DNA-DNA relatedness for the definition of bacterial species (Wayne et al., 1987), this value indicated that strain $\mathrm{Y}^{\mathrm{T}}$ did not belong to any known species.

For cellular fatty acid analysis, strain $\mathrm{Y} 4^{\mathrm{T}}$ was cultivated on TSA at $28{ }^{\circ} \mathrm{C}$ for $48 \mathrm{~h}$. Fatty acids were extracted, prepared, identified and quantified according to the Microbial Identification System (Sasser, 1990). The major fatty acids of strain $\mathrm{Y}^{\mathrm{T}}{ }^{\mathrm{T}}$ were iso- $\mathrm{C}_{15: 0} \quad(33.41 \%)$, iso- $\mathrm{C}_{17: 1} \omega 9 \mathrm{c}$ $(20.75 \%)$, iso- $\mathrm{C}_{16: 0}(9.27 \%)$ and iso- $\mathrm{C}_{17: 0}(8.89 \%)$, which were in large agreement with those determined for members of the genus Luteimonas under the same conditions and 
methodology (Table 2). Some differences with the reference strains were observed, especially in the proportions of iso$\mathrm{C}_{17: 0}$ in the isolate and L. aquatica RIB1-20 2 .

Isoprenoid quinones were extracted and purified as described by Collins et al. (1987) and subsequently analysed by HPLC (Wu et al. 1989). The predominant ubiquinone in strain $\mathrm{Y}^{\mathrm{T}}$ was $\mathrm{Q}-8$, which is as expected for members of the genus Luteimonas.

Sensitivity to antibiotics of strain $\mathrm{Y}^{\mathrm{T}}$ was tested using the method described by Chou et al. (2008) for the following ( $\mu$ g per disc, unless otherwise indicated): ampicillin (10), chloramphenicol (30), gentamicin (10), kanamycin (30), nalidixic acid (30), novobiocin (30), penicillin G (10), rifampicin (5), streptomycin (10), sulfamethoxazole (30) and tetracycline (30). After 3 days of cultivation, strain $\mathrm{Y}^{\mathrm{T}}$ was assessed to be resistant to penicillin $G$ and sulfamethoxazole, but susceptible to kanamycin, chloramphenicol, gentamicin, rifampicin, novobiocin, nalidixic acid, streptomycin, tetracycline and ampicillin.

On the basis of phylogenetic, phenotypic and chemotaxonomic data, strain $\mathrm{Y}^{\mathrm{T}}$ represents a novel species of the

Table 2. Cellular fatty acid compositions of strain $Y 4^{\top}$ and related Luteimonas species.

Strains: $1, \mathrm{Y}^{\mathrm{T}}$; 2, L. aquatica RIB1 $-20^{\mathrm{T}}$ (Chou et al., 2008); 3, L. composti CC-YY255 ${ }^{\mathrm{T}}$ (Young et al., 2007); 4, L. mephitis DSM $12574^{\mathrm{T}}$ (Young et al., 2007); 5, L. marina FR1330 ${ }^{\mathrm{T}}$ (Baik et al., 2008); 6, L. aestuarii $\mathrm{B} 9^{\mathrm{T}}$ (Roh et al., 2008). All data were taken after cultivation on TSA at $28{ }^{\circ} \mathrm{C}$ for $48 \mathrm{~h}$. ECL, Equivalent chain-length; -, not detected $<1 \%$.

\begin{tabular}{|c|c|c|c|c|c|c|}
\hline Fatty acid (\%) & 1 & 2 & 3 & 4 & 5 & 6 \\
\hline \multicolumn{7}{|l|}{ Saturated straight-chain } \\
\hline $\mathrm{C}_{14: 0}$ & - & - & - & - & - & 1.7 \\
\hline $\mathrm{C}_{16: 0}$ & 2.1 & 2.4 & 4.7 & 1.6 & 5.9 & 3.6 \\
\hline $\mathrm{C}_{18: 0}$ & - & - & - & - & 2.8 & - \\
\hline \multicolumn{7}{|l|}{ Saturated branched } \\
\hline iso- $\mathrm{C}_{11: 0}$ & 6.0 & 4.0 & 6.5 & 5.2 & 6.4 & 16.0 \\
\hline iso- $\mathrm{C}_{14: 0}$ & 1.7 & - & 1.9 & 1.5 & - & - \\
\hline iso- $\mathrm{C}_{15: 0}$ & 33.4 & 25.3 & 25.5 & 47.4 & 26.2 & 16.8 \\
\hline anteiso- $\mathrm{C}_{15: 0}$ & 4.8 & 6.2 & 2.7 & 3.0 & 4.5 & 4.0 \\
\hline iso- $\mathrm{C}_{16: 0}$ & 9.3 & 4.4 & 13.8 & 5.6 & 1.7 & 8.7 \\
\hline iso- $\mathrm{C}_{17: 0}$ & 8.9 & 21.5 & 5.5 & 5.5 & 14.5 & 10.7 \\
\hline anteiso- $\mathrm{C}_{17: 0}$ & - & 1.9 & - & - & - & - \\
\hline \multicolumn{7}{|l|}{ Unsaturated } \\
\hline iso- $\mathrm{C}_{15: 1}$ & - & - & 1.9 & 3.0 & 1.2 & - \\
\hline iso- $\mathrm{C}_{17: 1} \omega 9 c$ & 20.8 & 22.3 & 25.5 & 18.7 & 26.0 & 19.2 \\
\hline \multicolumn{7}{|l|}{ Hydroxy } \\
\hline iso- $\mathrm{C}_{11: 0} 3-\mathrm{OH}$ & 6.6 & 6.7 & 5.5 & 5.3 & 4.7 & 10.1 \\
\hline Summed feature $3^{*}$ & 3.0 & 1.4 & 5.5 & - & 2.2 & - \\
\hline Unknown ECL 11.799 & - & 1.5 & - & - & - & - \\
\hline
\end{tabular}

* Summed features represent two or three fatty acids that cannot be separated by the Microbial Identification System. Summed feature 3 consisted of $\mathrm{C}_{16: 1} \omega 7 c$ and/or iso- $\mathrm{C}_{15: 0} 2-\mathrm{OH}$. genus Luteimonas, for which the name Luteimonas cucumeris sp. nov. is proposed.

\section{Description of Luteimonas cucumeris sp. nov.}

Luteimonas cucumeris (cu.cu'me.ris. L. gen. n. cucumeris of a cucumber).

Cells are Gram-negative, aerobic and non-motile rods. After $72 \mathrm{~h}$ at $30{ }^{\circ} \mathrm{C}$ on NA, cells are $0.5-0.6 \mu \mathrm{m}$ wide and $2.0-3.0 \mu \mathrm{m}$ long. Colonies are approximately $1.5-2.0 \mathrm{~mm}$ in diameter, yellow and round with umbonate elevations and smooth edges. Grows at $20-40{ }^{\circ} \mathrm{C}$ (optimum $30{ }^{\circ} \mathrm{C}$ ), with $0-3 \% \mathrm{NaCl}$ (optimum $0 \% \mathrm{NaCl}$ ) and at $\mathrm{pH} 6-8$ (optimum pH 7). Poly- $\beta$-hydroxybutyrate granules are not accumulated. Nitrate is reduced to nitrite. Catalase- and oxidase-positive. Hydrolyses gelatin, starch and Tween 60, but not casein, DNA or Tween 20. With GN2 MicroPlate, utilizes dextrin, Tween 40, D-fructose, D-glucose, methylpyruvate, succinic acid monomethyl ester, D-galactonic acid lactone, $\beta$-hydroxybutyric acid, $\alpha$-ketoglutaric acid, alaninamide, D-alanine, L-alanine, L-alanyl glycine, glycyl Laspartic acid, glycyl L-glutamic acid, L-histidine, L-threonine, urocanic acid, putrescine, glycerol and L-proline, weakly utilizes glycogen, succinic acid and L-asparagine, but does not utilize the other substrates in the GN2 system. With API $20 \mathrm{NE}$, positive result in tests for hydrolysis of aesculin and $\beta$-galactosidase, but negative result for indole production, glucose acidification, arginine dihydrolase, urease and assimilation of glucose, arabinose, mannose, mannitol, $\mathrm{N}$-acetylglucosamine, maltose, gluconate, caprate, adipate, malate, phenylacetate and citrate. With API ZYM, positive result for alkaline phosphatase, esterase (C4), esterase lipase (C8), leucine arylamidase, valine arylamidase, cystine arylamidase, acid phosphatase, $\alpha$ galactosidase, naphthol-AS-BI-phosphohydrolase, $\beta$-galactosidase and $\beta$-glucosidase, but negative result in tests for lipase (C14), trypsin, $\alpha$-chymotrypsin, $\beta$-glucuronidase, $\alpha$ glucosidase, $N$-acetyl- $\beta$-glucosaminidase, $\alpha$-mannosidase and $\alpha$-fucosidase. Resistant to penicillin $G$ and sulfamethoxazole, but sensitive to gentamicin, rifampicin, ampicillin, novobiocin, kanamycin, chloramphenicol, nalidixic acid, tetracycline and streptomycin. The predominant fatty acids are iso- $\mathrm{C}_{15: 0}$, iso- $\mathrm{C}_{17: 1} \omega 9 c$, iso- $\mathrm{C}_{16: 0}$ and iso$\mathrm{C}_{17: 0}$. The major ubiquinone is Q-8.

The type strain, $\mathrm{Y}^{\mathrm{T}}\left(=\right.$ CGMCC $1.10821^{\mathrm{T}}=$ KCTC $\left.23627^{\mathrm{T}}\right)$, was isolated from a cucumber leaf from east Beijing, People's Republic of China. The DNA G+C content of the type strain is $69.9 \mathrm{~mol} \%$.

\section{Acknowledgements}

This work was supported by the National Natural Science Foundation of China (no. 30870055, 30871464 and 31170035) and Natural Science Foundation of Shandong (no. ZR2010CQ042). We would like to thank Yunfu Wang for providing cucumber leaf samples, and Xiaoxia Zhang, Yang Liu, Jianli Zhang and Jiewei Wang for their technical advice. 


\section{Reference}

Baik, K. S., Park, S. C., Kim, M. S., Kim, E. M., Park, C., Chun, J. \& Seong, C. N. (2008). Luteimonas marina sp. nov., isolated from seawater. Int J Syst Evol Microbiol 58, 2904-2908.

Chou, J.-H., Cho, N.-T., Arun, A. B., Young, C.-C. \& Chen, W.-M. (2008). Luteimonas aquatica sp. nov., isolated from fresh water from Southern Taiwan. Int J Syst Evol Microbiol 58, 2051-2055.

Chun, J. \& Goodfellow, M. (1995). A phylogenetic analysis of the genus Nocardia with $16 \mathrm{~S}$ rRNA gene sequences. Int J Syst Bacteriol 45, 240-245.

Chun, J., Lee, J.-H., Jung, Y., Kim, M., Kim, S., Kim, B. K. \& Lim, Y.-W. (2007). EzTaxon: a web-based tool for the identification of prokaryotes based on $16 \mathrm{~S}$ ribosomal RNA gene sequences. Int J Syst Evol Microbiol 57, 2259-2261.

Chung, Y. C., Kobayashi, T., Kanai, H., Akiba, T. \& Kudo, T. (1995). Purification and properties of extracellular amylase from the hyperthermophilic archeon Thermococcus profundus DT5432. Appl Environ Microbiol 61, 1502-1506.

Collins, M. D., Howarth, O. W., Grund, E. \& Kroppenstedt, R. M. (1987). Isolation and structural determination of new members of the vitamin $\mathrm{K}_{2}$ series in Nocardia brasiliensis. FEMS Microbiol Lett 41, 35-39.

De Ley, J., Cattoir, H. \& Reynaerts, A. (1970). The quantitative measurement of DNA hybridization from renaturation rates. Eur $J$ Biochem 12, 133-142.

Dong, X., Xin, Y., Jian, W., Liu, X. \& Ling, D. (2000). Bifidobacterium thermacidophilum sp. nov., isolated from an anaerobic digester. Int $J$ Syst Evol Microbiol 50, 119-125.

Felsenstein, J. (1985). Confidence limits on phylogenies: an approach using the bootstrap. Evolution 39, 783-791.

Finkmann, W., Altendorf, K., Stackebrandt, E. \& Lipski, A. (2000). Characterization of $\mathrm{N}_{2} \mathrm{O}$-producing Xanthomonas-like isolates from biofilters as Stenotrophomonas nitritireducens sp. nov., Luteimonas mephitis gen. nov., sp. nov. and Pseudoxanthomonas broegbernensis gen. nov., sp. nov. Int J Syst Evol Microbiol 50, 273-282.

Fitch, W. M. (1971). Toward defining the course of evolution: minimum change for a specific tree topology. Syst Zool 20, 406-416.

Heery, D. M., Gannon, F. \& Powell, R. (1990). A simple method for subcloning DNA fragments from gel slices. Trends Genet 6, 173.

Kimura, M. (1980). A simple method for estimating evolutionary rates of base substitutions through comparative studies of nucleotide sequences. J Mol Evol 16, 111-120.

Lane, D. J. (1991). 16S/23S rRNA sequencing. In Nucleic Acid Techniques in Bacterial Systematics, pp. 115-175. Edited by E. Stackebrandt \& M. Goodfellow. Chichester: Wiley.

Mackie, T. \& McCartney, J. E. (1989). Organization of the clinical laboratory. In Mackie and McCartney's Practical Medical Microbiology, 13th edn, p. 21. Edited by J. G. Collee, J. P. Duguid, A. G. Fraser \& B. P. Marmion. Edinburgh: Churchill Livingstone.

Marmur, J. (1961). A procedure for the isolation of deoxyribonucleic acid from microorganisms. J Mol Biol 3, 208-218.
Powers, E. M. (1995). Efficacy of the Ryu nonstaining KOH technique for rapidly determining gram reactions of food-borne and waterborne bacteria and yeasts. Appl Environ Microbiol 61, 3756-3758.

Rainey, F. A., Ward-Rainey, N., Kroppenstedt, R. M. \& Stackebrandt, E. (1996). The genus Nocardiopsis represents a phylogenetically coherent taxon and a distinct actinomycete lineage: proposal of Nocardiopsaceae fam. nov. Int J Syst Bacteriol 46, 1088-1092.

Roh, S. W., Kim, K.-H., Nam, Y.-D., Chang, H.-W., Kim, M.-S., Yoon, J.-H., Oh, H.-M. \& Bae, J.-W. (2008). Luteimonas aestuarii sp. nov., isolated from tidal flat sediment. J Microbiol 46, 525-529.

Rubini, M. R., Silva-Ribeiro, R. T., Pomella, A. W., Maki, C. S., Araújo, W. L., Dos Santos, D. R. \& Azevedo, J. L. (2005). Diversity of endophytic fungal community of cacao (Theobroma cacao L.) and biological control of Crinipellis perniciosa, causal agent of witches' broom disease. Int J Biol Sci 1, 24-33.

Saitou, N. \& Nei, M. (1987). The neighbor-joining method: a new method for reconstructing phylogenetic trees. Mol Biol Evol 4, 406425.

Sasser, M. (1990). Identification of bacteria by gas chromatography of cellular fatty acids. MIDI Technical Note 101. Newark, DE: MIDI Inc.

Sly, L. I., Blackall, L. L., Kraat, P. C., Tian-Shen, T. \& Sangkhobol, V. (1986). The use of second derivative plots for the determination of mol\% guanine plus cytosine of DNA by the thermal denaturation method. J Microbiol Methods 5, 139-156.

Smibert, R. M. \& Krieg, N. R. (1994). Phenotypic characterization. In Methods for General and Molecular Bacteriology, pp. 607-654. Edited by P. Gerhardt, R. G. E. Murray, W. A. Wood \& N. R. Krieg. Washington, DC: American Society for Microbiology.

Tamura, K., Dudley, J., Nei, M. \& Kumar, S. (2007). MEGA4: Molecular evolutionary genetics analysis (MEGA) software version 4.0. Mol Biol Evol 24, 1596-1599.

Thompson, J. D., Gibson, T. J., Plewniak, F., Jeanmougin, F. \& Higgins, D. G. (1997). The CLUSTAL_X windows interface: flexible strategies for multiple sequence alignment aided by quality analysis tools. Nucleic Acids Res 25, 4876-4882.

Wayne, L. G., Brenner, D. J., Colwell, R. R., Grimont, P. A. D., Kandler, O., Krichevsky, M. I., Moore, L. H., Moore, W. E. C., Murray, R. G. E. \& other authors (1987). International Committee on Systematic Bacteriology. Report of the ad hoc committee on reconciliation of approaches to bacterial systematics. Int J Syst Bacteriol 37, 463-464.

Wu, C., Lu, X., Qin, M., Wang, Y. \& Ruan, J. (1989). Analysis of menaquinone compound in microbial cells by HPLC. Microbiology [English translation of Microbiology (Beijing)] 16, 176-178.

Young, C. C., Kämpfer, P., Chen, W. M., Yen, W. S., Arun, A. B., Lai, W. A., Shen, F. T., Rekha, P. D., Lin, K. Y. \& Chou, J. H. (2007). Luteimonas composti sp. nov., a moderately thermophilic bacterium isolated from food waste. Int J Syst Evol Microbiol 57, 741-744.

Zhang, D. C., Liu, H. C., Xin, Y. H., Zhou, Y. G., Schinner, F. \& Margesin, R. (2010). Luteimonas terricola sp. nov., a psychrophilic bacterium isolated from soil. Int J Syst Evol Microbiol 60, 15811584 . 